Revista Eletrônica de Direito Processual - REDP.

Rio de Janeiro. Ano 11. Volume 18. Número 2. Maio a Agosto de 2017

Periódico Quadrimestral da Pós-Graduação Stricto Sensu em Direito Processual da UERJ

Patrono: José Carlos Barbosa Moreira. ISSN 1982-7636. pp. 347-370

www.redp.uerj.br

\title{
ENSAIO SOBRE A EFETIVIDADE DA TUTELA COLETIVA EM PORTUGAL ${ }^{1}$
}

\section{ESSAY ON THE EFFECTIVENESS OF THE COLLECTIVE PROTECTION IN PORTUGAL}

\section{Luciano Picoli Gagno}

Doutor em direito processual pela USP, Mestre em direitos e garantias fundamentais pela FDV, Professor Doutor de direito processual na Universidade Vila Velha - UVV e na Faculdade de Direito Estácio de Sá Vitória - FESV. luciano.gagno@uvv.com.br

Barbara Evelyn Sad Santos

Advogada, graduada em Direito pela Universidade Vila Velha - UVV e pós-graduanda em Direito Público pela Faculdade Damásio. barbarasad18@gmail.com

RESUMO: A presente pesquisa tem o condão de analisar determinados aspectos acerca da sistemática do processo coletivo à luz da experiência com a jurisprudência portuguesa, possuindo como pano de fundo a investigação da tutela coletiva entendida como um direito fundamental. No que se refere à metodologia de pesquisa empregada, a abordagem é qualitativa, enquanto o método é o dedutivo e a técnica é a do levantamento bibliográfico e jurisprudencial. O referencial teórico está baseado na doutrina e na teoria de alguns autores citados no decorrer da pesquisa, entre eles destacam-se: Robert Alexy, Mauro Cappelletti e Bryant Garth. Além disso, este artigo é dividido em três seções, sendo a primeira um breve estudo acerca do acesso à justiça compreendido como um direito fundamental do cidadão. Já na segunda seção é realizado um paralelo com a primeira, porém a tutela coletiva - um ramo do acesso à justiça, é que passa a ser vista como um direito fundamental. Na terceira e última seção tem-se a análise de quatro julgados de dois tribunais superiores de Portugal, sendo eles o Supremo Tribunal de Justiça (STJ) e o Supremo Tribunal Administrativo

\footnotetext{
${ }^{1}$ Artigo recebido em 01/03/2017 e aprovado em 01/08/2017.
} 
Revista Eletrônica de Direito Processual - REDP.

Rio de Janeiro. Ano 11. Volume 18. Número 2. Maio a Agosto de 2017

Periódico Quadrimestral da Pós-Graduação Stricto Sensu em Direito Processual da UERJ

Patrono: José Carlos Barbosa Moreira. ISSN 1982-7636. pp. 347-370

www.redp.uerj.br

(STA), como meio de compreensão do processo coletivo em Portugal e de identificação de pontos que possam oferecer uma contribuição para a técnica processual coletiva brasileira. Como resultado, é verificado que à tutela coletiva é inevitável e imanente a uma visão substancial do direito fundamental de acesso à justiça, compreendido como um mandamento de otimização, que impõe a sua realização na maior medida possível.

PALAVRAS-CHAVE: Direito fundamental de acesso à justiça - Tutela coletiva Jurisprudência portuguesa - Ação popular em Portugal.

ABSTRACT: This essay aims to examine certain aspects concerning collective judicial process by the light of some Portuguese cases, having as base the collective judicial protection understood as a fundamental right. With regard to the employed research method, the approach is the qualitative one, while the method is the deductive and the technique is the bibliographic e jurisprudential research. The theoretical framework is based on the doctrine and theory of some of the cited authors during the research. Among them are Robert Alexy, Mauro Cappelletti and Bryant Garth. In addition, this paper is divided into three sections: the first one is a brief study on access to justice clarified as a fundamental right of the citizen. In the second section a parallel is made with the first one, but the collective judicial protection is therefore seen as a fundamental right. In the third and last section we have the analysis of four cases of two superior courts of Portugal, being them the Supreme Court of Justice (STJ) and the Supreme Administrative Court (STA), in order to understand the collective process in Portugal and to see which points that can offer a contribution for the brazilian collective procedural technic. As a result, it is found that collective judicial protection is inevitable and immanent for a substantial vision of the fundamental right of access to justice, understood like a orders of optimization, that may his realization in the biggest measure is possible.

KEYWORDS: Fundamental right of access to justice - Collective protection - Portuguese jurisprudence - Popular action in Portugal. 


\section{INTRODUÇÃO}

A presente pesquisa tem o condão de analisar a temática do processo coletivo, mais especificamente do processo coletivo em Portugal, com o escopo de responder a seguinte pergunta: quais contribuições o processo coletivo português pode oferecer ao brasileiro, principalmente em pontos como: legitimidade, cabimento e coisa julgada, contribuindo assim com o aprimoramento do acesso à justiça?

Para tanto, foi utilizado como pano de fundo o tema do acesso à justiça, sob a ótica dos direitos fundamentais, que dependem de prestações estatais positivas para serem realizados na maior medida possível.

Portugal foi o país escolhido por possuir um arcabouço jurídico similar ao do direito brasileiro, que foi colônia portuguesa e conviveu com o sistema jurídico luso por séculos, com um sistema pautado na lei e nos códigos como a principal fonte do direito, apesar das transformações e da aproximação com o common law ocorrida recentemente nos últimos anos.

Nesse sentido, o que se deseja saber é como em Portugal o processo coletivo é utilizado e se é efetivo ou não. Dessa maneira, algumas questões secundárias devem ser analisadas, como: como é a normatização e a utilização do processo coletivo em Portugal para a proteção de direitos metaindividuais? Quais tipos de direitos podem ser objeto de tutela coletiva em Portugal? Quem são as partes legitimas para pleitear a sua proteção? É o que será aferido ao longo do trabalho.

No que se refere à metodologia desta pesquisa, a abordagem foi qualitativa, observando-se o método dedutivo, que parte de regras gerais para concluir sobre casos concretos, sendo utilizado levantamento bibliográfico e jurisprudencial relativo a decisões do Supremo Tribunal de Justiça e do Supremo Tribunal Administrativo de Portugal, por meio da pesquisa em meios eletrônicos, que deram suporte à compreensão do tema determinado.

Destarte, no primeiro tópico do trabalho foi pesquisado o significado do direito fundamental de acesso à justiça, que impõe a realização de prestações positivas a fim de se obter o maior nível de satisfação possível, em sentido convergente ao preconizado pelas ondas renovatórias do acesso à justiça, que defendem a gratuidade, a tutela de direitos 
Revista Eletrônica de Direito Processual - REDP.

Rio de Janeiro. Ano 11. Volume 18. Número 2. Maio a Agosto de 2017

Periódico Quadrimestral da Pós-Graduação Stricto Sensu em Direito Processual da UERJ

Patrono: José Carlos Barbosa Moreira. ISSN 1982-7636. pp. 347-370

www.redp.uerj.br

difusos e a mudança no modelo de atuação do Judiciário, como forma de melhoramento dos serviços jurisdicionais.

Já no segundo tópico é analisada a questão da tutela coletiva ser um consectário lógico do direito fundamental de acesso à justiça, tentando-se entender o seu formato geral no atual sistema brasileiro, tomando para tanto, como ponto de partida, o entendimento de pontos como: cabimento, legitimidade e coisa julgada, que apresentam mudanças substanciais em relação ao esquema de tutela individual.

Por fim, no terceiro tópico foram analisados quatro julgados, sendo dois do STJ (Supremo Tribunal de Justiça) português e mais dois do STA português (Supremo Tribunal Administrativo), relativos à tutela coletiva de direitos metaindividuais.

Nos dois primeiros julgados do STJ, que se tratavam de duas ações populares, uma não teve o mérito analisado, por se entender que o seu objeto era um direito individual subjetivo, que não apresentava uma dimensão coletiva, e outra que foi admitida justamente pelo fundamento inverso, tendo o mérito julgado para se determinar a tutela de direito difuso.

Já nos dois julgados do STA, em ambos também houve a analise do mérito, sendo que no primeiro se julgou questão relativa à legitimidade do sindicato para reivindicar direitos individuais e coletivos da categoria, e no segundo se analisou a legitimidade individual para a propositura de ação popular, cujo objeto era ato administrativo que autorizava construção particular em local supostamente público e de maneira avessa às normas de edificabilidade.

Este estudo é social e juridicamente relevante, pois os resultados obtidos poderão interferir diretamente na forma como a tutela coletiva é entendida e utilizada no Brasil, contribuindo para um maior investimento em seu aperfeiçoamento legislativo e jurisdicional, pelo acolhimento de técnicas que busquem a proteção do direito fundamental de acesso à justiça na maior medida possível.

\section{DO DIREITO FUNDAMENTAL DE ACESSO À JUSTIÇA}

Inicialmente, o propósito desta seção é o de proceder a uma breve análise do que seja o acesso à justiça, investigando-o sob o prisma dos direitos fundamentais, contudo, 
Revista Eletrônica de Direito Processual - REDP.

Rio de Janeiro. Ano 11. Volume 18. Número 2. Maio a Agosto de 2017

Periódico Quadrimestral da Pós-Graduação Stricto Sensu em Direito Processual da UERJ

Patrono: José Carlos Barbosa Moreira. ISSN 1982-7636. pp. 347-370

www.redp.uerj.br

mostra-se importante também, quando se discorre a respeito do acesso à justiça, mencionar a obra de Mauro Cappelletti e Bryant Garth ${ }^{2}$.

Tais autores retratam a temática do acesso à justiça entendendo haver três "ondas renovatórias" no direito processual civil. A primeira onda é a da a assistência judiciária para os mais necessitados, a segunda é a da representação dos interesses difusos e a terceira a de uma concepção mais ampla de acesso à justiça.

Não é o nosso objetivo um relato detalhado do que Mauro Cappelletti e Bryant Garth (1988) discutem em sua pesquisa, todavia, se faz relevante um singelo resumo do que seja cada uma das ondas, já que repercutem no grau de satisfação do direito fundamental de acesso à justiça, se comunicando diretamente com ele e com a teoria dos direitos fundamentais aqui adotada.

A primeira das ondas traz a compreensão de que o auxílio de um advogado se torna essencial ao cidadão, competindo ao Estado a providência de uma assistência judiciária a quem não pode pagar pelas custas de um processo judicial (gratuidade de justiça) ou até mesmo pelos serviços de um advogado (Defensoria Pública e advogados dativo). No direito brasileiro é perceptível que a Constituição da República de 1988, em seu artigo $5^{\circ}$, inciso LXXIV, entende que: “[...] o Estado prestará assistência jurídica integral e gratuita aos que comprovarem insuficiência de recursos". ${ }^{3}$

A segunda onda tratou da representação dos interesses difusos, ou seja, aqueles pertencentes ao grupo dos chamados direitos coletivos. Nos dizeres dos citados autores ${ }^{4}$ :

A concepção tradicional do processo civil não deixava espaço para a proteção dos direitos difusos. O processo era visto apenas como um assunto entre duas partes, que se destinava à solução de uma controvérsia entre essas mesmas partes a respeito de seus próprios interesses individuais. Direitos que pertencessem a um grupo, ao público em geral ou a um segmento do público não se enquadravam bem nesse esquema. As regras determinantes da legitimidade, as normas de procedimento e a atuação dos juízes não eram destinadas a facilitar as demandas por interesses difusos intentadas por particulares.

A segunda onda representou grande amplitude para o acesso à justiça, por conta da preocupação com a tutela coletiva, ocasionando uma superação de conceitos e ideias individualistas tradicionais do processo civil brasileiro, em total sintonia com a Lei de

${ }^{2}$ CAPPELLETTI, Mauro; GARTH, Bryan. Acesso à Justiça. Porto Alegre: Sergio Antônio Fabris editor, 1988

${ }^{3}$ BRASIL, 2016 .

${ }^{4}$ CAPPELLETI; GARTH, 1988, p. 49, op. cit. nota 4. 
Ação Civil Pública e o Código de Defesa do Consumidor. No caso desta pesquisa, essa onda é a que mais se aproximado tema a ser estudado, qual seja: tutela coletiva.

A terceira onda trata de uma concepção mais ampla do acesso à justiça. De fato, ela trouxe um novo enfoque do acesso à justiça, pela qual os autores trabalham a reflexão acerca de uma reforma dos procedimentos judiciais em geral, e projetam métodos alternativos para decidir as causas judiciais, como a conciliação e o juízo arbitral.

Nessa perspectiva, na ideia dos supracitados doutrinadores “[...] a preocupação fundamental é, cada vez mais, com a 'justiça social', isto é, com a busca de procedimentos que sejam conducentes à proteção dos direitos das pessoas comuns." ${ }^{5} \mathrm{Na}$ concepção de Candido Rangel Dinamarco:

\begin{abstract}
Acesso à justiça é acesso à ordem jurídica justa [...]. É a obtenção da justiça substancial. [...] Acesso à justiça não equivale a mero ingresso em juízo. A própria garantia constitucional da ação seria algo inoperante e muito pobre quando se resumisse a assegurar que as pretensões das pessoas cheguem ao processo, sem garantir-lhes também tratamento adequado. [...] Só tem acesso à ordem jurídica justa quem recebe justiça. E receber justiça significa ser admitido em juízo [...] e, ao fim, receber um provimento jurisdicional consentâneo com os valores da sociedade. ${ }^{6}$
\end{abstract}

Dinamarco $^{7}$ afirma a necessidade de uma universalização da jurisdição, no sentido de: “[...] endereçá-la a uma maior abrangência factível [...] para a efetividade das promessas de tutela jurisdicional solenemente celebradas na Constituição." O autor entende que:

As promessas e limitações residentes nas diversas garantias constitucionais [...] têm um só e único objetivo central, que é o acesso à justiça. O processo justo, celebrado com meios adequados e produtor de resultados justos, é o portador de tutela jurisdicional a quem tem razão, negando proteção a quem não a tenha. ${ }^{8}$

Ficou consignado em outra pesquisa, que a Carta Magna de 1988 retrata uma mudança na forma com que os Direitos Humanos passaram a ser tratados no Brasil, por

\footnotetext{
${ }^{5}$ Ibid., p. 93

${ }^{6}$ DINAMARCO, Candido Rangel. Instituições de direito processual civil. 7. ed. São Paulo: Malheiros, 2013, p. 118, grifos do autor

${ }^{7}$ Ibid., p.116

${ }^{8}$ Ibid., p. 267, grifos do autor
} 
Revista Eletrônica de Direito Processual - REDP.

Rio de Janeiro. Ano 11. Volume 18. Número 2. Maio a Agosto de 2017

Periódico Quadrimestral da Pós-Graduação Stricto Sensu em Direito Processual da UERJ

Patrono: José Carlos Barbosa Moreira. ISSN 1982-7636. pp. 347-370

www.redp.uerj.br

meio da: “[...] positivação da dignidade da pessoa humana como fundamento da República Federativa do Brasil." 9

Pelo fato de a dignidade da pessoa humana ser um termo polissêmico, ele comporta um rol de direitos fundamentais de maneira expressa na Constituição, dentre eles o de acesso à justiça.

Ocorre que, o termo acesso à justiça não se discerne de maneira exclusivamente formal, devendo ser enxergado como uma: “[...] garantia de justiça e efetividade [...]" 10 . Sem o acesso à justiça, na perspectiva do citado autor:

[...] não se poderia falar em Estado de Direito, mas em estado de injustiça [...], pois um homem sem direitos ou num simulacro de direitos não será livre nem igual, não tendo sua dignidade respeitada [...]. [...] Quando um homem é privado de qualquer direito, mesmo que seja de mero acesso a um bem material, perde um pouco de sua humanidade, não por deixar de ser humano, mas por deixar de ser tratado como um homem [...]. ${ }^{11}$

Nesse pensar, os direitos fundamentais impõem prestações positivas por parte do Estado, sendo certo que: “[...] não há liberdade nem igualdade sem o acesso à tutela dos direitos [...]” pois: “[...] não basta somente a garantia formal de acesso à justiça, mediante enunciados normativos contidos no Diploma Político [...]" 12

No mesmo sentido, verificou-se que, se os enunciados forem desvinculados de uma postura Estatal comprometida com os direitos fundamentais: “[...] seria equivalente a nada dizer $[\ldots] " 13$

O acesso à justiça surge, então, sob a perspectiva de ser um direito fundamental do cidadão. Alexy ${ }^{14}$ entende que, na maioria dos casos, as normas de direitos fundamentais são caracterizadas como princípios. Há casos, no entanto, em que são veiculados por meio de regras.

Nesse sentido, para o autor, enquanto os princípios são mandamentos de otimização, as regras são determinações. Isso porque, segundo ele, os princípios, por dependerem de possibilidades jurídicas e fáticas existentes, não contêm, em verdade: “[...]

\footnotetext{
${ }^{9}$ GAGNO, Luciano Picoli. A prova no processo civil: uma análise sob a ótica do direito fundamental de acesso à justiça. Rio de Janeiro: Lumemjuris, 2015, p. 16.

${ }^{10}$ Ibid., p. 16

${ }^{11}$ Ibid., 2015, p. 20-22

12 Ibid., p. 24 e 25.

13 Ibid., 2015, p. 25.

${ }^{14}$ ALEXY, Robert. Teoria dos direitos fundamentais. São Paulo: Malheiros, 2008, p.104.
} 
Revista Eletrônica de Direito Processual - REDP.

Rio de Janeiro. Ano 11. Volume 18. Número 2. Maio a Agosto de 2017

Periódico Quadrimestral da Pós-Graduação Stricto Sensu em Direito Processual da UERJ

Patrono: José Carlos Barbosa Moreira. ISSN 1982-7636. pp. 347-370

www.redp.uerj.br

um mandamento definitivo, mas apenas prima facie [...]" ${ }^{15}$, uma vez que: “[...] princípios representam razões que podem ser afastadas por razões antagônicas.” 16

Quanto às regras, no entanto, não existe possibilidade de mudança no que se refere aos seus mandamentos, por isso é que Alexy as considera como sendo determinações. Assevera, entretanto, que: “[...] essa determinação pode falhar diante de impossibilidades jurídicas e fáticas; mas, se isso não ocorrer, então, vale definitivamente aquilo que a regra prescreve" 17

Nessa mesma perspectiva, para nós as normas relativas ao acesso à justiça devem ser compreendidas como deveres impostos ao Estado - entenda-se legislador e juiz. Tais deveres são os de elaboração e aperfeiçoamento da técnica processual, de forma que: “[...] o acesso à justiça seja garantido na maior medida possível" 18

Nesse sentido é que Alexy aduz que as normas de direito fundamental têm um caráter principiológico, por serem mandamentos de otimização. Nesses moldes já foi lecionado que:

[...] o direito fundamental de acesso à justiça, para que tenha sua eficácia controlada pelos indivíduos e atendida pelo Judiciário, deve ser tido, também, como um direito subjetivo, exigível pelos cidadãos das instâncias estatais (legislativo e judiciário), a quem compete a proteção de tal direito [...]. [...] o direito fundamental de acesso à justiça deve denotar uma justiça substancial, e não o mero direito de ingresso com demandas, sendo exigido, por consequência, principalmente do Poder Judiciário [...] um constante aperfeiçoamento da prestação jurisdicional, através da utilização de técnicas processuais [...] mais aptas ao alcance de tal resultado $\left[\ldots . . .{ }^{19}\right.$

Desta forma, o que se tem, no entendimento citado, é a existência de normas abertas, consentâneas com os tempos atuais, que preceituam um: “[...] pluralismo e dinamismo [...]" ${ }^{20}$. Nesse sentido, entende-se que o magistrado, por exemplo, não pode valer-se, quando da aplicação do direito, de um: “[...] formalismo intransigente [...]" ${ }^{21}$. Cappelletti e Garth, no mesmo sentido, entendem que: “[...] Não se trata, contudo, apenas

\footnotetext{
${ }^{15}$ Ibid., p. 104, grifos do autor,

${ }^{16}$ Ibid, p. 104.

${ }^{17}$ Ibid., p. 104.

${ }^{18}$ GAGNO, 2015, p. 28, op. cit. nota 11.

${ }^{19}$ Ibid., p. 30

${ }^{20}$ Ibid., p. 32

${ }^{21}$ Ibid., 2015, p. 34
} 
Revista Eletrônica de Direito Processual - REDP.

Rio de Janeiro. Ano 11. Volume 18. Número 2. Maio a Agosto de 2017

Periódico Quadrimestral da Pós-Graduação Stricto Sensu em Direito Processual da UERJ

Patrono: José Carlos Barbosa Moreira. ISSN 1982-7636. pp. 347-370

www.redp.uerj.br

de expansão dos poderes processuais, mas também, sobretudo, daqueles poderes criativos e de evolução jurisprudencial do direito [...]" 22 .

Assim, na perspectiva dos mencionados autores, o que se deseja do julgador é: “[...] uma postura mais comprometida com os valores humanísticos e com os fins propostos por eles [...]" 23, na tentativa de obstar pareceres/sentenças/juízos contrários ou mesmo incompatíveis com os valores que fazem alusão aos direitos humanos fundamentais, isto é, atentando-se a um novo olhar sobre o ideal de justiça.

\section{A TUTELA COLETIVA COMO UM DIREITO FUNDAMENTAL}

Hodiernamente, a sociedade revela-se dinâmica e complexa, abarcando grande diversidade de pensamentos e ideias, sendo capaz de reunir opiniões diversas sobre as mesmas questões sociais. Diante da fluidez dos tempos atuais, dez anos somam uma proporção desmedida em termos de avanços tecnológicos e culturais. Nesse sentido, se um agrupamento social ou um povo reorienta-se, logo a tendência é uma nova forma de enxergar as relações humanas e, consequentemente, o Direito.

No cenário atual, pode-se constatar que uma razoável forma de se efetivar o acesso à justiça como um direito fundamental é concedendo aos cidadãos meios mais eficazes para a tutela de seus interesses indivisíveis ou homogêneos, uma vez que, atualmente, o número de processos judiciais tem aumentado consideravelmente, principalmente os repetitivos, o que torna cada vez mais morosa a realização daquilo que idealizamos por justiça.

O real acesso à justiça se dá proporcionando ao jurisdicionado a decisão mais justa possível, no menor tem possível, como já citado anteriormente; nesse sentido, ressalta-se que a tutela de interesses coletivos se apresenta como alternativa face à quantidade de demandas judiciais baseadas em questões comuns nos fóruns e varas de todo o país.

Enfatizando a necessidade de tutela dos direitos difusos, Cappelletti e Garth aduzem que: "[...] confrontando com os fenômenos da massificação [...], o indivíduo

${ }^{22}$ CAPPELLETTI; GARTH , 1988, p. 60, op. cit. nota 4.

${ }^{23}$ GAGNO, 2015, p. 37, op. cit. nota 11. 
Revista Eletrônica de Direito Processual - REDP.

Rio de Janeiro. Ano 11. Volume 18. Número 2. Maio a Agosto de 2017

Periódico Quadrimestral da Pós-Graduação Stricto Sensu em Direito Processual da UERJ

Patrono: José Carlos Barbosa Moreira. ISSN 1982-7636. pp. 347-370

www.redp.uerj.br

mostra-se simplesmente incapaz de se proteger por si mesmo de forma adequada. Nas sociedades contemporâneas o indivíduo isolado é desarmado." 24

Assim, se o acesso à justiça para a tutela de direitos individuais merece ser visto como um direito fundamental, nada mais justo que reconhecer o mesmo nos casos envolvendo a tutela dos direitos metaindividuais (coletivos lato sensu). No pensar de Cappelletti e Garth:

Em tempos recentes, pessoas envolvidas em ditos conflitos, violações e prejuízos de massa têm procurado descobrir meios eficazes de tutela [...]. "Classactions" e "public interest litigation" nos Estados Unidos, "actions collectives" e "Verbandsklagen" na França, Bélgica, Alemanha e outros lugares, são os símbolos do novo e acentuado papel dos tribunais judiciários: essas formas substancialmente novas de ação e lide judiciária tornaram-se típicos exemplos, no plano processual, do fenômeno de massificação acima descrito, cuja importância se torna difícil exagerar. ${ }^{25}$

Um belo exemplo dessa vertente da tutela coletiva visando à otimização do serviço jurisdicional pode ser extraído do ordenamento jurídico português, que por meio da "acção popular" oferece um mecanismo de tutela dos direitos metaindividuais de forma mais abrangente que a ação popular brasileira, como se extrai do trecho do julgado abaixo, do Supremo Tribunal de Justiça de Portugal:

[...] A acção popular pode ser intentada por um qualquer cidadão, ou por pessoas com interesses individuais homogéneos, invocando ou não o interesse público, mas terá de ser sempre uma acção em defesa de um interesse público geral e dos direitos subjectivos nesses direitos incluídos. Não é, portanto, qualquer interesse meramente individual e egoístico que pode estar na base de uma acção popular. Muito embora a lei atribua legitimidade processual a qualquer pessoa singular para intentar tal acção popular, os direitos que se pretende ver tutelados deverão ter um carácter comunitário, ou seja, um valor pluri-subjectivo e os interesses subjacentes devem assumir um cunho meta-individual. ${ }^{26}$

No ordenamento jurídico brasileiro, a tutela coletiva deve ser vista sob a perspectiva do acesso à justiça como um direito fundamental, que traz em seu âmago um mandamento constitucional: a inafastabilidade da tutela judiciário, como dispõe o artigo $5^{\circ}$, inciso XXXV da Lei Maior da República.

O Código brasileiro de Defesa do Consumidor, por sua vez, realiza, por meio do artigo 81, uma espécie de subdivisão e conceituação dos direitos coletivos em: difusos, coletivos stricto sensu e individuais homogêneos.

\footnotetext{
${ }^{24}$ CAPPELLETTI; GARTH 1988, p. 58, op. cit. nota 4.

${ }^{25}$ Ibid., p. 57, grifos do autor

${ }^{26}$ Processo no: 05B2578JSTJ000; Relator Min. Araujo Barros.
} 
Revista Eletrônica de Direito Processual - REDP.

Rio de Janeiro. Ano 11. Volume 18. Número 2. Maio a Agosto de 2017

Periódico Quadrimestral da Pós-Graduação Stricto Sensu em Direito Processual da UERJ

Patrono: José Carlos Barbosa Moreira. ISSN 1982-7636. pp. 347-370

www.redp.uerj.br

Os direitos difusos são transindividuais porque pertencem a uma coletividade; têm natureza indivisível, porque só podem ser considerados como um todo, sendo sua titularidade indeterminada e concernente a pessoas ligadas por uma circunstância de fato, ou seja, quando não existe vínculo de natureza jurídica prévio entre as tais.

Já os direitos coletivos stricto sensu, também pertencem a uma coletividade, uma vez que são transindividuais; tais direitos continuam tendo a natureza indivisível, mas em que pese as pessoas serem indeterminadas, são determináveis, já que existe uma relação jurídica base anterior à lesão sofrida.

Quanto aos direitos individuais homogêneos - acidentalmente coletivos ${ }^{27}$, são individuais e, portanto, divisíveis, mas são tutelados de forma coletiva por possuírem uma origem comum, seja ela fática ou jurídica ${ }^{28}$, o que lhe confere homogeneidade e possibilidade de tratamento molecularizado.

Nesse sentido, no que se refere à tutela coletiva, vale destacar dois aspectos de notável importância para melhor compreensão deste estudo: a legitimidade para propor uma ação que trata dos interesses de uma coletividade e os efeitos da coisa julgada nesses casos.

Identifica-se na doutrina a classificação da legitimação em: ordinária, extraordinária e autônoma para o ajuizamento da demanda, no entanto, no pensar de Didier Júnior e Zaneti Júnior, o terceiro tipo de legitimação é: “[...] uma categoria desnecessária e equivocada. Misturam-se conceitos jurídicos processuais fundamentais, comprometendo a qualidade e a inteligibilidade da argumentação jurídica." 29

Nesse sentido, explicam:

Há legitimação ordinária quando se atribui a um ente o poder de conduzir validamente um processo em que se discute uma situação jurídica de que se afirma titular. Há legitimação extraordinária quando se atribui a um ente o poder de conduzir validamente um processo em que se discute situação jurídica cuja titularidade afirmada é de outro sujeito. $\mathrm{Na}$ legitimação ordinária, age-se em nome próprio na defesa dos próprios interesses; na legitimação extraordinária, age-se em nome próprio na defesa de interesse alheio. ${ }^{30}$

\footnotetext{
${ }^{27}$ MENDES, Aluisio Gonçalves de Castro. Ações coletivas no direito comparado e nacional. São Paulo: Revista dos Tribunais, 2010, p. 225.

${ }^{28}$ Ibid., p. 225.

29 DIDIER JÚNIOR, Fredie; ZANETI JÚNIOR, Hermes. Curso de direito processual civil: processo coletivo. 9.ed. Salvador: Juspodium, 2014, p. 180.

${ }^{30}$ Ibid., p. 178, grifo dos autores.
} 
Revista Eletrônica de Direito Processual - REDP.

Rio de Janeiro. Ano 11. Volume 18. Número 2. Maio a Agosto de 2017

Periódico Quadrimestral da Pós-Graduação Stricto Sensu em Direito Processual da UERJ

Patrono: José Carlos Barbosa Moreira. ISSN 1982-7636. pp. 347-370

www.redp.uerj.br

Para eles ${ }^{31}$, a legitimação no processo coletivo se enquadra na dita extraordinária, visto que: “[...] autoriza-se um ente a defender, em juízo, situação jurídica de que é titular um grupo ou uma coletividade. Não há coincidência entre o legitimado e o titular da situação jurídica discutida."

Já no que tange aos efeitos da coisa julgada coletiva, registram-se dos autores antes citados, quando explicam acerca de cada um dos efeitos. A coisa julgada é analisada por eles a partir das três vertentes, quais sejam: “[...] os limites subjetivos - quem se submete à coisa julgada; b) os limites objetivos - o que se submete aos seus efeitos; c) e o modo de produção - como ela se forma." 32

Os limites subjetivos da coisa julgada dividem-se em: interpartes (os efeitos da coisa julgada somente vinculam as partes do processo judicial), ultra partes (os efeitos atingem somente pessoas ligadas a grupo, classe ou categoria) e erga omnes (os efeitos atingem a todos).

No que se refere aos limites objetivos somente se submete à coisa julgada material o dispositivo da decisão, que corresponde ao pedido contido na inicial - a questão principal, também denominada de mérito do processo.

No que tange ao modo de produção, há três tipos de coisa julgada, sendo eles: a coisa julgada pro et contra, pela qual, independentemente do resultado do processo (procedente ou improcedente) a coisa julgada se forma, o que é observado no modelo individual de processos.

Em segundo lugar está a coisa julgada secundum eventum litis, que, diferentemente da primeira hipótese, só faz coisa julgada no caso de procedência dos pedidos. Em outras palavras, se ocorrer a improcedência da demanda, a decisão não produz coisa julgada material que afete aos direitos individuais, podendo ser ajuizadas as respectivas demandas individuais ${ }^{33}$.

Por último, a coisa julgada secundum eventum probationis, que ocorre quando há procedência da ação ou improcedência baseada nas provas, não ocorrendo quando houver improcedência por falta de provas, situação que poderá ser revisada caso seja apresentada

\footnotetext{
${ }^{31}$ Ibid., p. 178.

${ }^{32}$ Ibid., p. 333, grifos dos autores.

${ }^{33}$ GRINOVER, Ada Pellegrini; MULLENIX, Linda; WATANABE, Kazuo. Os processos coletivos nos países de civil Law e common law: uma analise de direito comparado. São Paulo: Revista dos Tribunais, 2008, p. 243-244.
} 
Revista Eletrônica de Direito Processual - REDP.

Rio de Janeiro. Ano 11. Volume 18. Número 2. Maio a Agosto de 2017

Periódico Quadrimestral da Pós-Graduação Stricto Sensu em Direito Processual da UERJ

Patrono: José Carlos Barbosa Moreira. ISSN 1982-7636. pp. 347-370

www.redp.uerj.br

uma prova diferente. Parcela da doutrina denomina essa forma de imutabilidade, de coisa julgada secundum eventum litis também ${ }^{34}$, o que não concordamos, pois dá denominação idêntica a instituições e técnicas diferentes, prejudicando a clareza buscada pela ciência.

No sistema jurídico coletivo brasileiro, a coisa julgada secundum eventum litis é utilizada quando se tratam de direitos individuais homogêneos, de modo que tais direitos só possam ser beneficiados por uma coisa julgada coletiva, nunca sendo prejudicados em caso de improcedência dos pedidos.

A coisa julgada secundum eventum probationis em nosso sistema fica reservada aos casos envolvendo direitos indivisíveis (difusos ou coletivos stricto sensu), de modo que tais direitos só possam ser prejudicados pela imutabilidade de uma sentença de improcedência baseada nas provas produzidas nos autos, sendo permitida a repropositura de demanda coletiva idêntica, se a improcedência se basear na falta de provas e forem indicados novos elementos probatórios.

\section{ANÁliSe DE JULGAdOS DO SUPREMO TRIBUNAL DE JUSTIÇA E DO SUPREMO TRIBUNAL ADMINISTRATIVO DE PORTUGAL}

Nesta seção intenta-se realizar um breve estudo de julgados de duas das principais cortes federais portuguesas, quais sejam: o Supremo Tribunal de Justiça (STJ) e o Supremo Tribunal Administrativo (STA), analisando-se dois julgados de cada uma delas, buscandose compreender melhor a aplicação da tutela coletiva em Portugal, o que nos permitirá uma compreensão mais aguda e critica do ordenamento jurídico brasileiro, em decorrência da proximidade existente entre nossos sistemas jurídicos.

\subsection{DOS JULGADOS DO SUPREMO TRIBUNAL DE JUSTIÇA DE PORTUGAL}

De início, considera-se o acórdão do processo de número 05B2578JSTJ000²5, do STJ. Trata-se de ação civil individual que foi intitulada como ação popular, o que não era o caso. Pelo artigo $52^{\circ}$, número 3 , da Constituição Portuguesa observa-se que:

\footnotetext{
${ }^{34}$ Ibid., p. 240-241.

${ }^{35}$ Acórdão do dia 03/02/2005, relatoria ministro ARAÚJO BARROS.
} 
Revista Eletrônica de Direito Processual - REDP.

Rio de Janeiro. Ano 11. Volume 18. Número 2. Maio a Agosto de 2017

Periódico Quadrimestral da Pós-Graduação Stricto Sensu em Direito Processual da UERJ

Patrono: José Carlos Barbosa Moreira. ISSN 1982-7636. pp. 347-370

www.redp.uerj.br

É conferido a todos, pessoalmente ou através de associações de defesa dos interesses em causa, o direito de acção popular nos casos e termos previstos na lei, incluindo o direito de requerer para o lesado ou lesados a correspondente indemnização, nomeadamente para: a) Promover a prevenção, a cessação ou a perseguição judicial das infracções contra a saúde pública, os direitos dos consumidores, a qualidade de vida, a preservação do ambiente e do património cultural; b) Assegurar a defesa dos bens do Estado, das regiões autónomas e das autarquias locais. ${ }^{36}$

Por meio de tal artigo é possível verificar a existência de um rol para que a ação popular portuguesa seja utilizada, não sendo qualquer interesse individual capaz de ser tutelado por tal ferramenta.

No caso, o acórdão estudado narra que A e B intentaram, no Tribunal judicial de Cartaxo, uma ação contra $\mathrm{C}$ e $\mathrm{D}$, pedindo que fosse declarado como domínio público do município de Azambuja a parcela respeitante ao antigo pedaço da estrada municipal que identificam na petição inicial, visto que são donos de dois terrenos, e que os réus, por sua vez, também são donos de outro terreno, de sorte que tanto o terreno dos autores quanto o terreno dos réus são limítrofes a um antigo pedaço de uma estrada municipal.

$\mathrm{O}$ autor requereu à câmara municipal de Azambuja determinada licença para abrir uma porta/entrada em seu terreno, que daria para o pedaço da dita estrada, pois que na época das vindimas havia necessidade de melhorar os acessos do local, para a carga e descarga das uvas que são destinadas às adegas posteriormente.

$\mathrm{O}$ pedido de licença fora reprovado sob o fundamento de que a dita parcela respeitante ao pedaço da antiga estrada passou a integrar o terreno dos réus. Sendo assim, os autores não aceitaram tal deliberação, uma vez que para eles tal pedaço se mantinha integrando o domínio público do município de Azambuja, já que alegavam que sempre o utilizavam sem qualquer tipo de restrição na época da colheita de uvas. Ocorre que, a parcela em questão havia sido permutada entre a Câmara Municipal de Azambuja e os réus há cerca de quarenta e cinco anos.

Para ilustrar melhor o que é a ação popular portuguesa, Mariana Sotto Maior ilustra que:

O direito de acção popular é um direito de acção judicial, em que a legitimidade não é averiguada de modo concreto e casuístico, afastandose a noção de interesse directo e pessoal, sendo antes aferida em termos gerais e abstractos, a partir da integração objectiva de certas qualidades ou, inserção em determinada categoria de indivíduos. O interesse a

${ }^{36}$ PORTUGAL, 2016 ${ }^{\mathrm{a}}$ 
Revista Eletrônica de Direito Processual - REDP.

Rio de Janeiro. Ano 11. Volume 18. Número 2. Maio a Agosto de 2017

Periódico Quadrimestral da Pós-Graduação Stricto Sensu em Direito Processual da UERJ

Patrono: José Carlos Barbosa Moreira. ISSN 1982-7636. pp. 347-370

www.redp.uerj.br

prosseguir deve ser suficientemente difuso e geral para não se identificar com o interesse pessoal do seu agente. Está em causa a prossecução dum interesse público, pois, é a partir da noção de colectividade política que se opera a atribuição do direito de acção popular. ${ }^{37}$

$\mathrm{Na}$ hipótese em tela, os autores, ao realizarem seus questionamentos, não imputaram aos réus qualquer ato que importasse em violação de interesses metaindividuais, nem alegaram qualquer fato fundamentador de ação popular, antes desejaram a tutela de seu eventual direito subjetivo de acesso à suposta via municipal, o que fez com que a ação fosse considera equivocada, uma vez que não se enquadrava em qualquer situação próxima do rol constitucional mencionado.

Verificou-se no caso, que o interesse da lide não era um interesse metaindividual, coletivo, nem possuía qualquer caráter comunitário, por tratar-se de interesse individual, particular, entre vizinhos, de acesso a uma via pública.

Tal decisão, apesar de obstar o uso do processo coletivo, não obstou o uso do individual, muito pelo contrário, apontando-o como a forma adequada, o que desconfigura qualquer suspeita de óbice ao direito fundamental de acesso à justiça.

Por outro lado, ao decidir que no caso em concreto não havia interesse metaindividual a ser tutelado, fincou o entendimento de que, se a veiculação de pretensão sobre coisa pública estiver direcionada a proporcionar beneficio exclusivamente particular, não se pode taxá-la como fundamento para uma ação coletiva.

Já no processo número 08B2450JSTJ000 ${ }^{38}$, também do STJ português, A e B entraram com uma ação popular contra seus vizinhos $C$ e $D$ pedindo que os réus fossem condenados a reconhecer que determinado caminho que separa os respectivos terrenos era público, de uso comum dos moradores da vizinhança e arredores, sendo necessária a demolição de anexos construídos naquele local público pelos réus.

Em resposta, os réus, alegando ilegitimidade dos autores e abuso de direito, contestaram o alegado. O Tribunal da Relação de Coimbra, em acórdão, decidiu que as partes eram legítimas e, além disso, que a demanda em tela se tratava sim de uma ação popular, dada a natureza difusa do interesse, uma vez que, a partir da construção dos

37 MAIOR, Mariana Sotto. O direito de acção popular na constituição da república portuguesa. Disponível em: 〈http://www.gddc.pt/actividade-editorial/pdfs-publicacoes/7576-g.pdf>. Acesso em: $12 \mathrm{dez}$ 2016, p. 249.

${ }^{38}$ Acórdão do dia 28/05/2009, relatoria da ministra MARIA DOS PRAZERES PIZARRO BELEZA. 
Revista Eletrônica de Direito Processual - REDP.

Rio de Janeiro. Ano 11. Volume 18. Número 2. Maio a Agosto de 2017

Periódico Quadrimestral da Pós-Graduação Stricto Sensu em Direito Processual da UERJ

Patrono: José Carlos Barbosa Moreira. ISSN 1982-7636. pp. 347-370

www.redp.uerj.br

anexos pelos réus, que havia sido aprovada pelo município, o caminho ficou obstado para todos os moradores e usuários do local para encurtamento de distâncias.

Em sentença, os réus foram condenados a reconhecer que o dito caminho era, efetivamente, um caminho público, a demolir os anexos questionados pelos autores e a pagar, como multa por eventual atraso na demolição, a quantia de 100 euros por dia. A sentença foi confirmada pelo Tribunal da Relação de Coimbra e os réus recorreram para o Supremo Tribunal de Justiça. No referido acórdão, aduziu-se que:

É suficiente para que uma coisa seja pública o seu uso directo e imediato pelo público, não sendo necessária a sua apropriação, produção, administração ou jurisdição por pessoa coletiva de direito público. Assim,um caminho é público desde que seja utilizado livremente por todas as pessoas, sendo irrelevante a qualidade da pessoaque o construiu e prove a sua manutenção.[...] Basta, portanto, para a qualificação de um caminho como caminho público o facto de certa faixa de terreno estar afeta ao trânsito de pessoas sem discriminação $0^{39}$.

Assim, salientou-se que o caminho é parte integrante da coisa pública, destinado à satisfação de interesses coletivos relevantes, como o direito de ir e vir dos habitantes do entorno, direito este extirpado por aqueles que construíram propriedade particular no local onde havia livre trânsito de pessoas por mais de meio século.

Nesse sentido, tratava-se de ação popular, cujo objeto rompia o interesse próprio dos autores, pois o que se buscou foi a defesa de interesse público e do caráter comunitário de utilização comum da estrada. Desta feita, o recurso dos réus ao STJ teve negado o seu provimento.

O direito fundamental de acesso à justiça foi garantido quando reconhecida a legitimidade e o cabimento da ação no caso, não tendo sido colocado qualquer obstáculo ilegítimo, que impedisse a tutela ao respectivo direito coletivo.

Nada obstante, se transportado o caso para a realidade jurídica brasileira, fica a seguinte pergunta: no Brasil o Judiciário aceitaria uma ação popular movida contra indivíduos que invadem área pública, visando-se à remoção de construção ilícita, ou para o seu cabimento teria que necessariamente haver um ato administrativo ilegal ou inconstitucional, que fosse objeto de impugnação também, juntamente com a invasão?

\footnotetext{
${ }^{39}$ Acórdão do dia 28/05/2009, relatoria da ministra MARIA DOS PRAZERES PIZARRO BELEZA.
} 
Revista Eletrônica de Direito Processual - REDP.

Rio de Janeiro. Ano 11. Volume 18. Número 2. Maio a Agosto de 2017

Periódico Quadrimestral da Pós-Graduação Stricto Sensu em Direito Processual da UERJ

Patrono: José Carlos Barbosa Moreira. ISSN 1982-7636. pp. 347-370

www.redp.uerj.br

É nesse sentir que a experiência portuguesa deve iluminar a prática brasileira e alargar as vias de acesso à justiça, proporcionando mais participação e maior efetividade a promessa constitucional de tutela dos direitos.

\subsection{DOS JULGADOS DO SUPREMO TRIBUNAL ADMINISTRATIVO (STA)}

Neste trecho da pesquisa passa-se à análise de dois julgados do Supremo Tribunal Administrativo de Portugal. O primeiro trata do processo de número 0788/10. ${ }^{40}$

No caso, o sindicato de professores da região centro ingressou com ação contra o ministério da educação de Portugal. O sindicato intentou no TAF (Tribunal Administrativo e Fiscal) de Coimbra um processo de Intimação para Proteção de Direitos, Liberdades e Garantias contra o Ministério de Educação com base no artigo $109^{\circ}$ do CPTA (Código de Processo dos Tribunais Administrativos), que preconiza o seguinte:

1 - A intimação para protecção de direitos, liberdades e garantias pode ser requerida quando a célere emissão de uma decisão de mérito que imponha à Administração a adopção de uma conduta positiva ou negativa se revele indispensável para assegurar o exercício, em tempo útil, de um direito, liberdade ou garantia, por não ser possível ou suficiente, nas circunstâncias do caso, o decretamento provisório de uma providência cautelar $[\ldots] .{ }^{41}$

O sindicato reivindicava que tal ministério desfizesse determinado procedimento concursal, que previa, para efeito de graduação profissional e fator de ponderação entre os candidatos, a classificação obtida pelos associados quando da avaliação de desempenho.

Alternativamente, pediu-se a intimação do requerido para adotar as medidas necessárias a fim de proceder a uma adequação do procedimento concursal para que as classificações não se baseassem na impugnada avaliação.

O sindicato entendia que a avaliação de desempenho era ilegal, embora muitos de seus associados tivessem obtido a classificação "muito bom" e "excelente", isto é, ingressou com a ação para buscar um direito coletivo de todos os professores filiados, qual seja: a igualdade no tratamento e no acesso à função pública, pugnando, assim, pelo afastamento da avaliação de desempenho.

\footnotetext{
${ }^{40}$ Acórdão do dia 16/12/2010, cujo relator foi o ministro ANTÓNIO BENTO SÃO PEDRO.

${ }^{41}$ PORTUGAL, 2016b.
} 
Revista Eletrônica de Direito Processual - REDP.

Rio de Janeiro. Ano 11. Volume 18. Número 2. Maio a Agosto de 2017

Periódico Quadrimestral da Pós-Graduação Stricto Sensu em Direito Processual da UERJ

Patrono: José Carlos Barbosa Moreira. ISSN 1982-7636. pp. 347-370

www.redp.uerj.br

Em resposta, o Ministério da Educação opôs-se aos pedidos, alegando a ilegitimidade ativa do sindicato, que estaria se voltando contra os interesses de alguns filiados, e impugnando os fatos apresentados. A sentença, no entanto, considerou o disposto no $n^{\circ} 2$ do artigo $310^{\circ}$ da lei portuguesa de $n^{\circ} 59 / 2008$ :

2 - É reconhecida às associações sindicais legitimidade processual para defesa dos direitos e interesses colectivos e para a defesa colectiva dos direitos e interesses individuais legalmente protegidos dos trabalhadores que representem. ${ }^{42}$

Em outras palavras, a sentença considerou que o sindicato é detentor da legitimidade ativa para pleitear em favor dos seus associados na causa em questão. Interposto recurso, o acórdão do TCA - Sul (Tribunal Central Administrativo Sul) julgou procedente a exceção de ilegitimidade ativa do sindicato, que recorreu o STA.

Além do conflito existente acerca de a demanda ser ou não um interesse coletivo de toda a categoria, o que refletia na questão da legitimidade, havia ainda um impasse devido ao determinado pela lei acima mencionada, com relação ao pagamento ou isenção de custas, conforme art. $310^{\circ}, n^{\circ} 3$, por meio do qual: “As associações sindicais beneficiam da isenção do pagamento das custas para defesa dos direitos e interesses colectivos, aplicando-se no demais o regime previsto no Regulamento das Custas Processuais." 43

Nesse sentido, foi afirmado pelo requerido, que somente teriam isenção de custas as associações sindicais que pleiteiam direitos e interesses considerados coletivos, de toda a categoria, suscitando aí uma dúvida se a demanda tratava de interesses coletivos ou apenas de interesses individuais de determinados professores, sendo que, se considerados individuais, afirmou-se que não seria devida a isenção das custas processuais.

Os interesses coletivos, no entanto, são caracterizados pela indivisibilidade, ou seja, um ente, no caso o sindicato, ingressa com a ação em nome de seus associados e representando a todos, de forma conjunta, e o resultado aproveita a todos, por ser indivisível a relação objeto do processo. Dessa maneira, O STA, em sede do acórdão analisado, entendeu que:

[...] embora o sindicato tenha uma ampla legitimidade processual para defender interesses dos seus associados, a verdade é que os requisitos de uma e outra das apontadas modalidades não são iguais: (i) Pode defender direitos ou interesses colectivos, sem ter que identificar qualquer dos associados, mas os direitos e interesses a prosseguir devem ser comuns e

${ }^{42}$ PORTUGAL, 2016c.

${ }^{43}$ PORTUGAL, 2016c. 
Revista Eletrônica de Direito Processual - REDP.

Rio de Janeiro. Ano 11. Volume 18. Número 2. Maio a Agosto de 2017

Periódico Quadrimestral da Pós-Graduação Stricto Sensu em Direito Processual da UERJ

Patrono: José Carlos Barbosa Moreira. ISSN 1982-7636. pp. 347-370

www.redp.uerj.br

indivisíveis (colectivos). Nestes casos está isento de custas. (ii) Pode defender colectivamente direitos ou interesses individuais dos seus associados. Nestes casos não goza de isenção de custas. ${ }^{44}$

O referido acórdão ainda entendeu presente a legitimidade ativa do sindicato, que, em nome do acesso à função pública e da solidariedade ingressou com uma ação para dirimir as desigualdades estabelecidas entre trabalhadores da mesma categoria (professores) em um concurso público, o que interessava a toda categoria profissional, ainda que isto "prejudicasse" - se que a perda de um benefício indevido pode ser considerada um prejuízo, àqueles que tiveram um bom desempenho, já que a "avaliação de desempenho" foi um critério classificatório considerado indevido.

Assim, verifica-se que o ideal de acesso à justiça como um direito fundamental prevaleceu sobre a pretensão restritiva da parte requerida, que sob o pretexto do sindicato não estar defendendo o interesse de toda a categoria, visava a restringir o cabimento da tutela coletiva e impor um óbice formal ao exame do mérito, o que não procedeu.

No processo de $\mathrm{n}^{\circ} 0989 / 11^{45}$, o caso se tratava de uma ação popular ajuizada pela parte A e outros no TAF (Tribunal Administrativo e Fiscal) do Porto contra o município do Porto e outros, questionando um despacho do vereador do Pelouro do Urbanismo e Mobilidade da Câmara Municipal do Porto, que licenciou a construção de três edifícios de uma das requeridas (I. S/A).

Impugnou-se também, o ato de emissão de alvará de licença de construção para os referidos edifícios, praticado pelo diretor do Departamento Municipal de Gestão Urbanística da Câmara Municipal do Porto, imputando a tais atos diversos vícios (violação do índice da área bruta de construção, previsto no regulamento de normas provisórias do Porto; consideração, na "edificabilidade" do prédio da recorrida particular, de parcelas de terrenos públicos municipais).

A sentença que julgou a ação popular decidiu pela legitimidade dos autores para a sua propositura, e pela improcedência da pretensão autoral, o que ensejou a interposição de dois recursos.

O primeiro, interposto pela requerida particular contra o despacho do MM. Juiz do TAF que considerou a legitimidade dos autores para propor ação popular. O segundo recurso foi interposto pelos autores da ação popular, contra a decisão que manteve o ato de

${ }^{44}$ STA; Acórdão do dia 16/12/2010, cujo relator foi o ministro ANTÓNIO BENTO SÃO PEDRO.

${ }^{45}$ Acórdão do dia 13/02/2014, cuja relatora foi a ministra MARIA FERNANDA DOS SANTOS MAÇÃS. 
Revista Eletrônica de Direito Processual - REDP.

Rio de Janeiro. Ano 11. Volume 18. Número 2. Maio a Agosto de 2017

Periódico Quadrimestral da Pós-Graduação Stricto Sensu em Direito Processual da UERJ

Patrono: José Carlos Barbosa Moreira. ISSN 1982-7636. pp. 347-370

www.redp.uerj.br

licenciamento para a construção dos já mencionados edifícios, julgando improcedente a invocada violação do índice de área bruta de construção ea utilização de área publica indevidamente.

No que se refere à alegação contida no recurso da empresa, a mesma aduziu que a parte autora não conseguiu provar qualquer prejuízo concreto ou real sobre os ditos atos e que pudesse colocar em xeque a análise feita antes, limitando-se a tratar de situações como a qualidade de vida dos habitantes da região, a harmonia da paisagem e o equilíbrio na ocupação do espaço urbano.

$\mathrm{O}$ TAF, no entanto, entendeu que os requerentes, estando no âmbito de uma ação popular administrativa, preenchidos todos os requisitos necessários ao ingresso da mesma, visam, na verdade, proteger o espaço e o ambiente urbano, além da qualidade de vida dos moradores da região. $\mathrm{O}$ art. $1^{\circ}, \mathrm{n}^{\circ} 2$ da lei portuguesa de $\mathrm{n}^{\circ} 83 / 95$ define os casos em que é cabível a ação popular em procedimentos administrativos:

2 - Sem prejuízo do disposto no número anterior, são designadamente interesses protegidos pela presente lei a saúde pública, o ambiente, a qualidade de vida, a protecção do consumo de bens e serviços, o património cultural e o domínio público. ${ }^{46}$

Nesse sentido, entendeu o tribunal por assistir legitimidade à parte autora, que pretendia proteger o ambiente urbano, julgando improcedente, portanto as alegações do recurso da empresa, como pode ser observado:

No despacho recorrido, concluiu-se pela legitimidade dos recorrentes, com base na jurisprudência deste Supremo Tribunal, que vai no sentido de que "[a] acção popular, cujo objecto é, antes de mais, a defesa de interesses difusos, traduz-se, por definição, num alargamento da legitimidade processual activa dos cidadãos, independente do seu interesse individual ou da sua relação específica com os bens ou interesses em causa". ${ }^{47}$

Já o segundo recurso, o STA entendeu que a câmara municipal do Porto aceitou que seus próprios terrenos integrassem a operação com a empresa I. S/A, por meio de parceria, objetivando a realização de interesses municipais, sendo que o dito licenciamento, recaído sobre toda a operação urbanística pensada de forma global, teria respeitado todos os valores máximos de edificabilidade.

Nesse sentido, tanto o primeiro quanto o segundo recursos tiveram seus provimentos negados, não obstante, não há que se falar em obstáculo ao acesso à justiça, a

${ }^{46}$ PORTUGAL, 2016d, grifo nosso.

${ }^{47}$ Acórdão do dia 13/02/2014, cuja relatora foi a ministra MARIA FERNANDA DOS SANTOS MAÇÃS. 
Revista Eletrônica de Direito Processual - REDP.

Rio de Janeiro. Ano 11. Volume 18. Número 2. Maio a Agosto de 2017

Periódico Quadrimestral da Pós-Graduação Stricto Sensu em Direito Processual da UERJ

Patrono: José Carlos Barbosa Moreira. ISSN 1982-7636. pp. 347-370

www.redp.uerj.br

menos a priori, vez que a legitimidade das partes foi reconhecida e a demanda teve seu mérito devidamente analisado.

\section{CONSIDERAÇÕES FINAIS}

Neste estudo se buscou observar a aplicação do direito coletivo numa perspectiva mais ampla e direcionada ao atendimento das novas demandas judiciais, as demandas em que um grupo de pessoas ou mesmo uma entidade em nome de um grupo aciona o Poder Judiciário a fim de pleitear direitos que correspondem àquele determinado conjunto de pessoas.

Na presente pesquisa foram trabalhadas três seções. Dessa forma, fora estudado na primeira seção o acesso à justiça como um direito um fundamental do cidadão, ou seja, como um valor que deve ser realizado na maior medida das possibilidades fáticas e jurídicas, principalmente por prestações positivas que ampliem e facilitem a prestação do serviço jurisdicional à sociedade.

Na segunda seção deste trabalho foi feita uma espécie de transição entre a ideia do acesso à justiça como um direito fundamental e a tutela coletiva vista como seu consectário lógico, uma vez que, se os indivíduos possuem o direito fundamental de acesso à justiça para buscarem a proteção dos seus direitos individuais, consequentemente tem o mesmo direito em relação aos direitos metaindividuais.

Nesse cenário, foram realizadas algumas considerações didáticas visando à situação do leitor sobre pontos essenciais do processo coletivo, ligados a institutos como: legitimidade e coisa julgada, o que permitiu a visualização da diferencia entre a legitimidade ordinária típica dos processos individuais e a extraordinária, típica dos processos coletivos, em que o autor não pleiteia a tutela de um direito seu, pelo menos não exclusivamente, atuando como substitutos de inúmeros beneficiários ausentes.

No que tange à coisa julgada, viu-se que no processo coletivo ela assume um formato diferente, denominado de secundum eventum litis, quando torna a decisão imutável apenas no caso de procedência da demanda, e secundum eventum probationis, quando torna a decisão imutável se de procedência ou de improcedência com base nas provas. 
Revista Eletrônica de Direito Processual - REDP.

Rio de Janeiro. Ano 11. Volume 18. Número 2. Maio a Agosto de 2017

Periódico Quadrimestral da Pós-Graduação Stricto Sensu em Direito Processual da UERJ

Patrono: José Carlos Barbosa Moreira. ISSN 1982-7636. pp. 347-370

www.redp.uerj.br

Já na terceira seção cuidou-se da análise de alguns julgados de dois tribunais superiores portugueses, sendo o Supremo Tribunal de Justiça (STJ) e o Supremo Tribunal Administrativo (STA).

O direito português fora escolhido por conta da similitude com o arcabouço jurídico dogmático brasileiro, de modo que, por meio de seu estudo é possível descobrir outras visões e entendimentos, para uma possível contribuição com o nosso ordenamento e a nossa prática.

Dessa maneira, foram escolhidos quatro julgados, isto é, quatro acórdãos, sendo dois de cada um dos citados tribunais, visando-se a uma interação qualitativa com eles, para se conhecer posicionamentos diferentes sobre temas afins, que podem ser melhor compreendidos e aplicados pela prática jurídica brasileira.

No primeiro julgado do STJ, por exemplo, foi visto que demandas que veiculam pretensões individuais, subjetivas, que não digam respeito ou não interessem a coletividade, não podem ser objeto de ações populares.

Por outro lado, no segundo julgado do STJ, foi visto que a ação popular em Portugal não está (nem mesmo no âmbito positivo), limitada a existência de ato administrativo ilegal ou inconstitucional, uma vez que foi examinada uma ação popular movida contra um ato invasão que impedia a passagem das pessoas em via pública, visando-se a demolição da construção ali existente.

Já no primeiro julgado do STA, viu-se a possibilidade de organizações com fins sociais, como os sindicatos, pleitearem a tutela de direitos indivisíveis ou individuais pertencentes a membro da categoria, havendo diferenças apenas no que tange ao pagamento de custas, mas sem restrição a legitimidade.

Por fim, no ultimo julgado examinado, também se decidiu pela legitimidade do individuo para o ajuizamento de ações populares administrativas, que visam a anulação de atos ilegais ou inconstitucionais, que violem a saúde, o ambiente ou a qualidade de vida das pessoas.

Destarte, percebeu-se que a temática do direito coletivo em Portugal é tratada de forma um pouco diferente do que no Brasil, uma vez que lá a tutela coletiva aparenta ser um tanto mais acessível aos cidadãos, que tem legitimidade individual para propor ação popular, com objeto que aparenta ser mais amplo que o previsto positivamente no 
Revista Eletrônica de Direito Processual - REDP.

Rio de Janeiro. Ano 11. Volume 18. Número 2. Maio a Agosto de 2017

Periódico Quadrimestral da Pós-Graduação Stricto Sensu em Direito Processual da UERJ

Patrono: José Carlos Barbosa Moreira. ISSN 1982-7636. pp. 347-370

www.redp.uerj.br

ordenamento brasileiro, indo além da impugnação de um ato administrativo ilícito ou inconstitucional, abrangendo quaisquer condutas que violem valores coletivos ou direitos individuais ligados a esses valores, o que se coaduna na maior medida com o direito fundamental de acesso à justiça para a tutela de direitos coletivos.

\section{REFERÊNCIAS BIBLIOGRÁFICAS:}

ALEXY, Robert. Teoria dos direitos fundamentais. São Paulo: Malheiros, 2008.

BRASIL. Constituição (1988). Constituição [da] República Federativa do Brasil. Brasilia. Disponível

em: <http://www.planalto.gov.br/ccivil_03/constituicao/ConstituicaoCompilado.htm>. Acesso em: 29 set.2016a.

Lei no 8.078, de 11 de Setembro de 1990. Brasília, 1990. Disponível em: <http://www.planalto.gov.br/ccivil_03/leis/L8078.htm>. Acesso em: 10 out. 2016b.

CAPPELLETTI, Mauro; GARTH, Bryant. Acesso à justiça. Porto Alegre: Sérgio Antônio Fabres Editor, 1988.

CINTRA, Antônio Carlos de Araújo; GRINOVER, Ada Pellegrini e DINAMARCO, Cândido Rangel. Teoria geral do processo. 30. ed. São Paulo: Malheiros, 2014.

DIDIER JÚNIOR, Fredie; ZANETI JÚNIOR, Hermes. Curso de direito processual civil: processo coletivo. 9.ed. Salvador: Juspodium, 2014.

DINAMARCO, Cândido Rangel. Instituições de direito processual civil. 7. ed. São Paulo: Malheiros, 2013.

GRINOVER, Ada Pellegrini; WATANABE, Kazuo; NERY JUNIOR, Nelson. Código brasileiro de defesa do consumidor comentado pelos autores do anteprojeto. Rio de Janeiro:Forense, 2011.

; MULLENIX, Linda; WATANABE, Kazuo. Os processos coletivos nos países de civil Law e common law: uma analise de direito comparado. São Paulo: Revista dos Tribunais, 2008.

GAGNO, Luciano Picoli. A prova no processo civil: uma análise sob a ótica do direito fundamental de acesso à justiça. Rio de Janeiro: Lumem Juris, 2015. 
Revista Eletrônica de Direito Processual - REDP.

Rio de Janeiro. Ano 11. Volume 18. Número 2. Maio a Agosto de 2017

Periódico Quadrimestral da Pós-Graduação Stricto Sensu em Direito Processual da UERJ

Patrono: José Carlos Barbosa Moreira. ISSN 1982-7636. pp. 347-370

www.redp.uerj.br

MAIOR, Mariana Sotto. O direito de acção popular na constituição da república

portuguesa. Disponível em: <http://www.gddc.pt/actividade-editorial/pdfspublicacoes/7576-g.pdf>. Acesso em: 12 dez 2016.

MENDES, Aluisio Gonçalves de Castro. Ações coletivas no direito comparado e nacional. São Paulo: Revista dos Tribunais, 2010.

PORTUGAl. Constituição (1974). Constituição da República Portuguesa. Lisboa.

Disponível

em:

<http://www.parlamento.pt/Legislacao/Paginas/ConstituicaoRepublicaPortuguesa.aspx >.

Acesso em: $11 \mathrm{dez} 2016 \mathrm{a}$.

Código de Processo nos Tribunais Administrativos. Lisboa, 2002. Disponível em:

<http://www.stadministrativo.pt/pdf/codigodeprocessonostribunaisadministrativos.pdf > Acesso em: $12 \mathrm{dez} 206 \mathrm{~b}$

Lei n. ${ }^{0}$ 59/2008 de 11 de Setembro. Lisboa, 2008. Disponível em: <https://www.uc.pt/fmuc/apresentacao/legislacao/lei59200811Setembro>. Acesso em: 13 $\operatorname{dez} 2016 c$.

Lei n. ${ }^{0}$ 83/95, de 31 de Agosto. Lisboa, 1995. Disponível em: <http://www.pgdlisboa.pt/leis/lei_mostra_articulado.php?nid=722\&tabela=leis>. Acesso em: 15 dez 2016 d. 